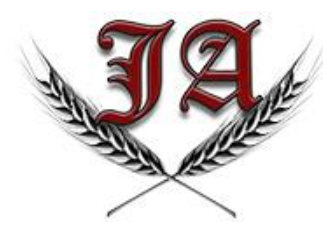

\title{
JOURNAL of AGRICULfURE
}

agrijournal@ hotmail.com

ISSN: 2636-8757

https://dergipark.org.tr/tr/pub/ja

DOI: $10.46876 / j a .750086$

Research / Araştırma

\section{ASSESSMENT IN-SITU MEASUREMENTS IN MONITORING WATER QUALITY STATUS OF LAKE AYGIR, BITLIS}

\author{
Asude ÇAVUŞ ${ }^{1}$ Fazıl ŞEN ${ }^{2}$
}

\begin{abstract}
In this study, analyzes were carried out monthly between May 2015 and May 2016 from the Lake Aygir and the irrigation pond for examining its water quality change and management. In-situ measurements were found as average water temperature $9.9 \pm 0.5^{\circ} \mathrm{C}, \mathrm{pH}$ $8.14 \pm 0.00$, dissolved oxygen $8.1 \pm 0.4 \mathrm{mg} . \mathrm{L}-1$, oxygen saturation $\% 76.6 \pm 2.4$, EC $353.1 \pm 4.1$, SPC $435.0 \pm 4.5 \mu$ S.cm-1, TDS $0.2881 \pm 0.0026$ g.L-1, turbidity $0.6 \pm 0.1 \mathrm{NTU}$ and transparency $5.8 \pm 0.7 \mathrm{~m}$. In terms of in-situ measurements, Lake Aygir is not polluted and is suitable for drinking, usage, fishery, and irrigation.
\end{abstract}

Key words: Lake Aygir, Water quality, In-situ measurements

\footnotetext{
T Sorumlu Yazarlar/Corresponding Authors :Asude ÇAVUŞ (Orcid ID: 0000-0001-8328-4675) Van Yüzüncü Y1l University, Faculty of Fisheries, Department of Basic Sciences, Turkey. a.gultekin@yyu.edu.tr

${ }^{2}$ Fazıl ŞEN (Orcid ID: 0000-0002-8650-3375) Van Yüzüncü Y1l University, Faculty of Fisheries, Department of Basic Sciences, Turkey. fazilsen@yyu.edu.tr

Makale Geliş Tarihi (Received): 11-06-2020

Makale Kabul Tarihi (Accepted): 25-06-2020
} 


\section{INTRODUCTION}

Water, covering three-quarters of the earth and indispensable for living things, is a source of life (Kemmer, 1988).

Water quality refers to the entire physical, chemical, and biological properties of water, in terms of the purpose of water usage. Water quality parameters significantly affect the physiological conditions, the productivity and abundance conditions of aquatic organisms living inland water (Çetinkaya, 2003).

Inland waters, which are the source of life of people; It has a very important place in vegetable production, transportation, tourism, and recreation. They are also used effectively throughout human history, as they host a rich biological population with valuable fish stocks (Çetinkaya et al., 1994).

Today some natural lake in Turkey is used as a reservoir. Lake Aygir, which is located in the Adilcevaz district of Bitlis, is an important reservoir because it is used for drinking, irrigation, and freshwater fishing. Besides, its tourism potential is quite high with its proximity to Lake Van and Mount Suphan and its natural beauty. However, as the lake mirror has become smaller, the coastal ecosystem has deteriorated and has been invaded by zebra mussels (Doğu and Deniz, 2015; Şen, 2017; Çavuş and Şen, 2018).

In this study, Lake Aygir was researched in terms of water quality and basin characteristics, which are important in terms of fisheries, drinking, recreation, and irrigation, were evaluated. The findings obtained from the examinations and observations made in the lake were evaluated and solutions were tried to be developed against the problems that may occur.

\section{MATERIALS AND METHODS}

\section{Characterization of the study area}

Aygir Lake is maar about $1.4 \mathrm{~km}^{2}$ in Bitlis in the east of Turkey and placed on the south side of Mount Suphan. Coordinates of the lake is $38^{\circ} 50^{\prime} 14^{\prime \prime} \mathrm{N}, 42^{\circ} 49^{\prime} 20^{\prime \prime}$ E, altitudes 1938 $\mathrm{m}$ (Doğu and Deniz, 2015; Çavuş, 2018). The water from the lake serves as a public supply to a town and irrigation (Güllü and Güzel, 2006; Elp et al., 2014).

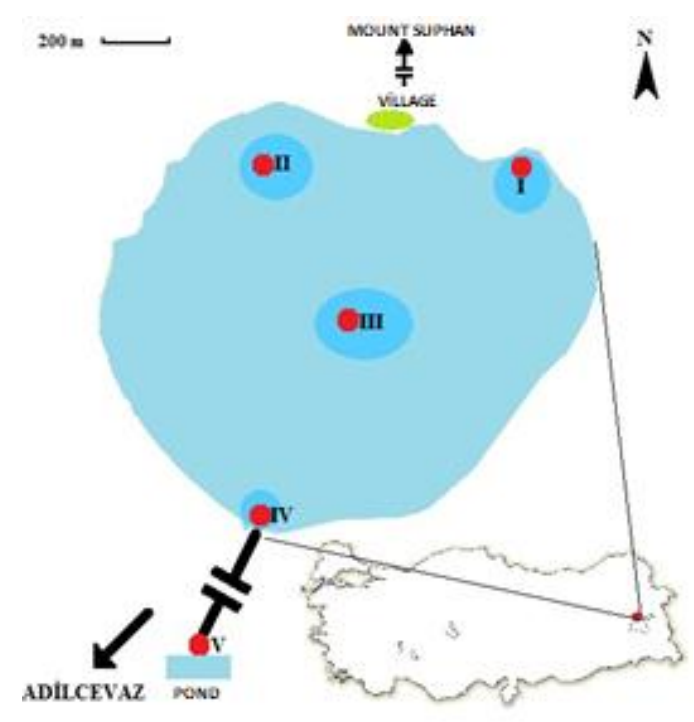

Figure 1. Lake Aygir (Bitlis) and five sampling points. 


\section{Sampling points location}

The sampling points in the Aygir Lake were defined as trout cages (I), across-village (II), a center of the lake (III), drainage of the lake (IV), irrigation pond (V) (Figure 1, Table 1).

I. station was selected for the detection of organic and inorganic nutrient loads released from four cages into the lake. II. station was chosen to reveal the possible effects of Lake Aygir Village on the lake. There is a low-flowing water source flowing through the village of Lake Aygir into the lake. Since the Lake Aygir is a maar lake, it has a shape close to the round, which facilitated the researchers in choosing the center point. III. station; It was chosen to determine the average properties of the lake. Agricultural irrigation and drinking water needs of Aydinlar Town are met by the channel opened by the special provincial administration. The point where the channel connects with the lake IV. It was chosen as the station. With the irrigation pond built by DSI (State Hydraulic Works), the lands to the south of Lake Aygir are irrigated. The V. station was chosen to measure the quality of the pond water.

Table 1. Sampling points information geographically.

\begin{tabular}{lllll}
\hline & \multicolumn{2}{c}{ Coordinates } & Depth & $\begin{array}{l}\text { Distances from } \\
\text { shore }\end{array}$ \\
\cline { 2 - 3 } & North & East & & \\
\hline I. station & $38^{\circ} 50^{\prime} 18.00^{\prime \prime}$ & $42^{\circ} 49^{\prime} 29.7^{\prime \prime}$ & $30 \mathrm{~m}$ & $\approx \sim 61 \mathrm{~m}$ \\
II. station & $38^{\circ} 50^{\prime} 28.56^{\prime \prime}$ & $42^{\circ} 49^{\prime} 14.82^{\prime \prime}$ & $30 \mathrm{~m}$ & $145 \mathrm{~m}$ \\
III. station & $38^{\circ} 50^{\prime} 6.66^{\prime \prime}$ & $42^{\circ} 50^{\prime} 22.92^{\prime \prime}$ & $40 \mathrm{~m}$ & $500 \mathrm{~m}$ \\
IV. station & $38^{\circ} 49^{\prime} 54.36^{\prime \prime}$ & $42^{\circ} 49^{\prime} 10.98^{\prime \prime}$ & $3-7 \mathrm{~m}$ & $40 \mathrm{~m}$ \\
V. station & $38^{\circ} 49^{\prime} 18.12^{\prime \prime}$ & $42^{\circ} 50^{\prime} 11.7^{\prime \prime}$ & - & $2910 \mathrm{~m}$ \\
\hline
\end{tabular}

\section{Sampling period}

Studies were carried out in monthly samples between May 2015 and May 2016. In January 2016, it was observed that multimeters did not present consistent measurements due to extreme cold. As a result, in-situ measurements could not be made.

Monthly in-situ measurements to determine some parameters that water temperature, dissolved oxygen (DO), oxygen saturation (OS), $\mathrm{pH}$ and electrical conductivity (EC) was measured with HACH $40 \mathrm{D}$ and YSI Pro Plus multimeters at different depths $(0 \mathrm{~m}, 15 \mathrm{~m}$, bottom), light transmittance was measured with Secchi disk, and turbidity measured with HACH 2100Q turbidimeter. A 4.20 m 2006 Zodiac brand Bombard Typhoon removable wooden-based inflatable boat and a boat-mounted outboard Yamaha brand $8 \mathrm{HP}$ model gasoline engine were used in transportation to sampling points. Water samples were taken from the surface $(0 \mathrm{~m}), 15 \mathrm{~m}$ depth, and lake bottom with Hydro-Bios Nansen bottle. The water in the bottle was used for the turbidimeter.

To determine the number of TDS (total dissolved solids) in $\mathrm{mg}_{\mathrm{L}} \mathrm{L}^{-1}$ in the lake by using the EC values obtained during the study, the TDS values were calculated by multiplying the 0.725 coefficient, determined by taking the average of the conversion factors reported between 0.55-0.90 (Golterman et al., 1978; Tuncay, 1994), and the EC values.

\section{RESULTS AND DISCUSSION}

The people of the village are engaged in agriculture and animal breeding, as well as 
aquaculture and fishing. They grow fruit trees and annual vegetables in their gardens. Due to its location, trout plant, and trout restaurant in the village, it has become one of the most beautiful promenade places of the district and the region. No industrial establishment was found in the region.

Doğu and Deniz (2015) found that there are streams (centripetal river network) that flows from the upper part of Mount Suphan in a fan-shaped way and flows seasonally; $\mathrm{He}$ reported that the streams fed with snow and glacial waters melting at the top of the mountain disappeared between the cracked volcanic rocks as they went down.

Carp, Van barb, Tarek and Rainbow trout grown in Lake Aygir and zebra mussels play an important biological and economical role in the aquatic ecosystem. On the lake, fishing is carried out by village people from time to time with 10-15 m extension nets (according to the fishermen's testimony). Lake Aygir has an important place in terms of angling in the region. Even in the winter, the ice layer is broken and fish can be fished in the lake with fishing rods.

Table 2. According to sampling months, the in-situ measurements values in Lake Aygir

\begin{tabular}{llllllllll}
\hline Mouths & $\begin{array}{l}\text { Temper. } \\
\left({ }^{\circ} \mathrm{C}\right)\end{array}$ & $\begin{array}{l}\mathrm{DO} \\
\left(\mathrm{mgL}^{-1}\right)\end{array}$ & $\begin{array}{l}\mathrm{OS} \\
(\%)\end{array}$ & $\mathrm{pH}$ & $\begin{array}{l}\mathrm{EC} \\
\left(\mu \mathrm{S} . \mathrm{cm}^{-1}\right)\end{array}$ & $\begin{array}{l}\mathrm{SPC} \\
\left(\mu{\left.\mathrm{S} . \mathrm{cm}^{-1}\right)}^{-1}\right.\end{array}$ & $\begin{array}{l}\text { Turbidity } \\
(\mathrm{NTU})\end{array}$ & $\begin{array}{l}\text { TDS } \\
\left({\left.\mathrm{mg} . \mathrm{L}^{-1}\right)}^{-1}\right.\end{array}$ & $\begin{array}{l}\text { Secchi } \\
\text { disc }(\mathrm{m})\end{array}$ \\
\hline May 15 & 8.8 & 9.3 & 101.6 & 8.2 & 328.4 & 419.7 & 1.2 & 278.6 & 1.78 \\
June 15 & 13.6 & 7.1 & 87.7 & 8.4 & 353.8 & 428.6 & 0.4 & 278.8 & 7.00 \\
July 15 & 13.2 & 7.9 & 80.2 & 7.9 & 338.3 & 363.9 & 0.5 & 282.7 & 6.89 \\
Aug. 15 & 12.8 & 7.6 & 66.9 & 8.2 & 340.6 & 434.8 & 0.8 & 283.4 & 8.78 \\
Sept. 15 & 13.0 & 7.5 & 72.7 & 7.9 & 398.2 & 446.8 & 1.0 & 300.1 & 8.28 \\
Oct. 15 & 11.9 & 7.2 & 67.9 & 8.0 & 370.4 & 451.5 & 0.5 & 284.0 & 8.40 \\
Nov. 15 & 8.4 & 6.3 & 54.8 & 8.1 & 388.9 & 458.7 & 0.5 & 298.1 & 4.79 \\
Dec. 15 & 6.1 & 6.0 & 48.6 & 8.1 & 386.3 & 439.5 & 0.4 & 285.7 & 4.41 \\
Jan. 16 & - & - & - & 8.5 & 355.2 & 424.1 & 0.3 & 274.8 & 6.54 \\
Feb. 16 & 5.0 & 9.2 & 90.2 & 8.5 & 374.7 & 448.7 & 0.4 & 293.1 & 3.51 \\
Mar.16 & 4.2 & 11.6 & 89.0 & 8.0 & 297.3 & 461.3 & 0.6 & 301.5 & 3.60 \\
April 16 & 9.1 & 8.7 & 74.9 & 8.0 & 320.9 & 435.1 & 0.5 & 288.3 & - \\
May 16 & 12.2 & 9.4 & 87.1 & 8.1 & 337.0 & 435.7 & 0.5 & 292.7 & - \\
\hline Average & $\mathbf{9 . 9} \pm \mathbf{0 . 5}$ & $\mathbf{8 . 1} \pm \mathbf{0 . 4}$ & $\mathbf{7 6 . 6 \pm 2 . 4}$ & $\mathbf{8 . 1} \pm \mathbf{0 . 1}$ & $\mathbf{3 5 3 . 1} \pm \mathbf{4 . 1}$ & $\mathbf{4 3 5 . 0} \pm \mathbf{4 . 5}$ & $\mathbf{0 . 6} \pm \mathbf{0 . 1}$ & $\mathbf{2 8 7 . 8} \pm \mathbf{2 . 4}$ & $\mathbf{5 . 8 2} \pm \mathbf{0 . 7 0}$
\end{tabular}

Temperature is very important for aquatic creatures. In aquaculture, it directly affects the feeding, growth, development, reproduction, respiration, circulation, and immune system development of fish. It is directly related to the oxygen solubility in water. Temperature also affects the taste of drinking water (Tanyolaç, 2009; Çetinkaya, 2003).

The monthly average temperature value of Lake Aygir was $9.9^{\circ} \mathrm{C}$. In January 2016, the icing was observed throughout the lake. In rainbow trout cultivation, it was observed that the water temperature was suitable up to 18 and $20^{\circ} \mathrm{C}$, and the water temperature in Lake Aygir generally did not exceed this limit. It was observed that there was no problem in growing trout since there was no excessive increase in summer months (Table 2; Emre and Kürüm, 2007). Lake Aygir has first-class water quality when its water temperature is classified according to SKKY. While in limit values according to TS 266 and UK (United Kingdom), it is in A1 class according to 76/464/EEC. The values given were found to be compatible according to freshwater fisheries water quality standards (78/659/EEC) (Tebbutt, 1998).

Some published temperature values available for Lake Van Basin were reported respectively $2-24.5^{\circ} \mathrm{C}, 1.5-23.5{ }^{\circ} \mathrm{C},-1.0-24.5{ }^{\circ} \mathrm{C}, 0.8-24.5{ }^{\circ} \mathrm{C},-0.3-20.7{ }^{\circ} \mathrm{C}, 0.2-24.1{ }^{\circ} \mathrm{C}, 9.53$ ${ }^{\circ} \mathrm{C}, 10.88{ }^{\circ} \mathrm{C}, 12.3{ }^{\circ} \mathrm{C}$ by Şen (2001), Elp (2002), Cantürk (2007), Şekerci (2011), Bulum (2015), Atıc1 (2017), Seyhan (2016), Bayram (2016), Çavuş et al. (2017).

While most of the DO in the stream passes through the water surface with the atmosphere, the ability of the stream to clean itself with oxygen is related to the water 
temperature, flow rate, aeration, and time. In addition to these factors, it is desirable to have the high OS in the stream and low BOD and COD (Nas et al., 2005). The average DO $8.1 \pm$ $0.4 \mathrm{mg} . \mathrm{L}^{-1}$ and $\mathrm{OS}$ value was determined as $76.6 \pm 2.4 \%$ in Lake Aygir (Table 2). While in SKKY, it is in the 1st quality waters class in terms of DO and II. in quality water class and A1 class according to 76/464 / EEC (Tebbutt, 1998). At the same time, when the criteria of trout farming were examined, average DO values were found suitable for cultivation (Emre and Kürüm, 2007).

Some published DO and OS values available for Lake Van Basin were reported respectively $8.2 \mathrm{mg} . \mathrm{L}^{-1}, 10.03 \mathrm{mg} . \mathrm{L}^{-1}$ and $\% 119.4,10.86 \mathrm{mg} . \mathrm{L}^{-1}$ and $\% 122.9,8.83 \mathrm{mg} . \mathrm{L}^{-1}$, $7.0 \mathrm{mg} . \mathrm{L}^{-1}, 10.06 \mathrm{mg} . \mathrm{L}^{-1}$ and $\% 107.43,6.53-16.50 \mathrm{mg} . \mathrm{L}^{-1}, 5.61 \mathrm{mg} . \mathrm{L}^{-1}$ by Cantürk (2007) Şekerci (2011), Bulum (2015), Bayram (2016), Atıc1 et al. (2016), Seyhan (2016) Atıc1 (2017), Çavuş et al. (2017).

$\mathrm{pH}$ is a parameter that determines the acid or alkaline properties of water. (Çetinkaya, 2003). Average of $\mathrm{pH} 8.14 \pm 0.06$ was found in Lake Aygir (Table 2). The $\mathrm{pH}$ values measured in this study fall into the first-class water quality class specified in SKKY (2004). Since the desired $\mathrm{pH}$ is between 6.5 and 9.0 in fish breeding, Lake Aygir is suitable for fish breeding. It is also suitable for drinking water since its $\mathrm{pH}$ value is between 6.5 and 9.5 according to İTASHY (Emre and Kürüm, 2007; Türkman et al., 1999;). Also, the pH value is among the limit values given in TS 266. While it is in A1 class according to 76/464 / EEC, it is found to comply with the standards in the UK, EPA, and the limit values given in freshwater fish (Tebbutt, 1998).

Some published $\mathrm{pH}$ values available for Lake Van Basin were reported respectively 9.70, 8.06-8.47, 8.01-9.18, 8.28, 8.23, 7.50-8.20, 8.54, 6.95, 8.40, 7.43, 8.36 by Şen (1995), Şen (2001), Elp (2002), Cantürk (2007), Şekerci (2011), Bulum (2015) Bayram (2016) Atıc1 et al. (2016) Seyhan (2016), Çavuş et al. (2017), Atıcı (2017).

It is called the opposite of electrical resistance of the water column with $1 \mathrm{~cm}$ length and $1 \mathrm{~cm}^{2}$ cross-sectional area at EC $25{ }^{\circ} \mathrm{C}$ (Çetinkaya, 2003). The average EC in the Lake Aygir was $353.1 \pm 4.1 \mu \mathrm{S} . \mathrm{cm}^{-1}$ (Table 2). The average EC value in the measurements made in Lake Aygir for thirteen months did not exceed the limits specified in TS 266 and ITASHY. When EC is evaluated at all sampling points, it is seen that it is not within the limits that will pose a problem in terms of human consumption and fisheries (Türkman et al., 1999; TSE, 2005; ITASHY, 2005). While it is well below the limit values given in the UK, it is in the A1 class according to 76/464 / EEC (Tebbutt, 1998).

The few published EC values available for Lake Van Basin were reported respectively

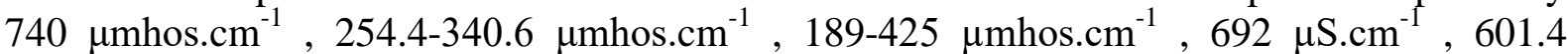
$\mu \mathrm{S} . \mathrm{cm}^{-1}, 680.47 \mu \mathrm{S} . \mathrm{cm}^{-1}, 350.1 \mu \mathrm{S} . \mathrm{cm}^{-1}, 697.13 \mu{\mathrm{S} . \mathrm{cm}^{-1}}^{-1}, 313.0 \mu \mathrm{S} . \mathrm{cm}^{-1}, 338-670 \mu \mathrm{S} . \mathrm{cm}^{-1}$, $578.7 \mu$ S.cm $^{-1}$ by Şen (1995), Şen (2001), Elp (2002), Cantürk (2007), Şekerci (2011), Bulum (2015), Bayram (2016), Seyhan (2016), Atıcı et al. (2016), Atıcı (2017), Çavuş et al. (2017).

Specific conductivity is an industrial standard that using water analysis because it is defined as the electrolytic conductivity between two centimeters of the medium and the separated cells. Specific conductivity, which is the simplified version of conductivity, is the type of conductivity that is claimed to be specific to water only (Anonymous, 2017). The average SPC (Specific conductivity) in Lake Aygir was $435.0 \pm 4.5 \mu{\mathrm{S} . \mathrm{cm}^{-1}}^{-}$(Table 2). 
The few published SPC values were reported respectively $2231 \mu{\mathrm{S} . \mathrm{cm}^{-1}}^{-1}, 42860 \mu \mathrm{S} . \mathrm{cm}^{-1}$ , $266 \mu \mathrm{S} . \mathrm{cm}^{-1}, 206-601 \mu \mathrm{S} . \mathrm{cm}^{-1}$ by Koçer (2008), Turkoglu and Oner (2010), Aydın (2015), Tuna and Ustaoğlu (2016).

The color of the Lake Aygir water is blue and clear. The average turbidity value in Lake Aygir was 0.6 NTU (Table 2). While Lake Aygir water samples are well below the limits specified in TS 266, they are within the limits given in ITASHY (TSE, 2005). While there are quite high values compared to the measurement results made in other water sources, the increasing turbidity values in the spring period were also found in our study. It was found to be within the limits given in the UK (4 NTU) and WHO (5 NTU) (Tebbutt, 1998). In EPA, it was found slightly above the limit value given.

The few published turbidity values available for Lake Van Basin were reported respectively 10.68 NTU, 3.50 NTU, 0.43 NTU, 17.10 NTU, 180 NTU, 1.07 NTU by Bulum (2015), Bayram (2016), Atıcı et al. (2016), Seyhan (2016), Atıcı (2017), Çavuş et al. (2017).

Silt, clay, small particles of organic structure, inorganic materials, soluble organic compounds, plankton, and other microscopic organisms compose TDS. The main ions that can be found in dissolved solids are $\mathrm{CO}_{3}, \mathrm{HCO}_{3}, \mathrm{Cl}, \mathrm{SO}_{4}, \mathrm{NO}_{3}, \mathrm{Na}, \mathrm{K}, \mathrm{Ca}$, and $\mathrm{Mg}$ (Taş and Çetin, 2011). The average TDS in Lake Aygir was 288.1 $\pm 2.6 \mathrm{mg}^{-\mathrm{L}^{-1}}$ (Table 2). When the results of the analysis are analyzed, our results were found among the values measured in other studies. According to SKKY, it was found in water class with first-class quality. It was found to comply with the standards below the limit values given in EPA $\left(500 \mathrm{mg} . \mathrm{L}^{-1}\right)$ and WHO (1000 mg.L $\left.\mathrm{L}^{-1}\right)$ (Tebbutt, 1998).

The published TDS values were reported respectively 190.39-225.98 mg. $\mathrm{L}^{-1}, 189-209$

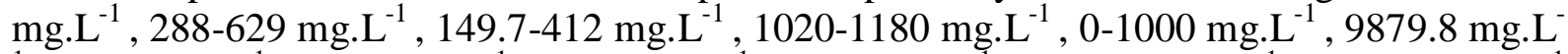

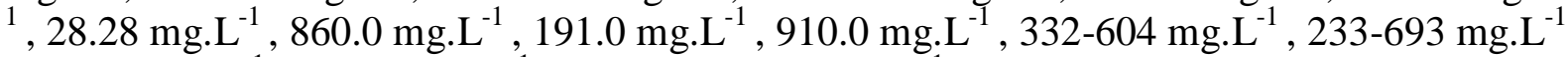
, 58-223 mg.L $\mathrm{L}^{-1}$, 168.66 mg.L. $\mathrm{L}^{-1}$, 196.93-2380.44 mg.L -1 $^{-1}$ by Şen (2001), Dişli (2002), Kurmaç (2003), Gülboy (2004), Taş (2006), Gündoğdu and Kocataş (2006), Zeybek (2006), Gedik et al. (2010), Yıldız (2013), Şengün (2013), Dinçer (2014), Kaya (2015), Baytaşoğlu and Şen (2015), Karagüllü (2015), Aydın (2015), Subka (2017).

Light transmittance is very important in terms of the amount of $\mathrm{O}_{2}$ used by phytoplankton and aquatic plants. The turbidity, created by seston substances, inorganic particles, organic detritus, and plankton, changes light transmittance (Cirik and Cirik, 2008). At the same time, light transmittance allows commenting on the yield of water (HendersonSellers and Markland, 1987). According to OECD (1982), light transmittance in lakes is classified as eutrophic at 0.8-1.5 m depth, mesotrophic at 1.4-2.4 m depth, and oligotrophic at 3.6-5.9 m depth (Ryding and Rast, 1989). The average Secchi disk value in Lake Aygir was $5.82 \pm 0.70 \mathrm{~m}$ (Table 2). Since the bottom of the lake appeared from August 2015 to May 2016 in IV. Station, Secchi depth measurement was not performed. The Lake Aygir was suitable for classifications of YSKY, OECD, and Hakanson and Jansson (1983) in terms of average light transmittance and was in the oligotrophic lake class with $5.82 \mathrm{~m}$.

The few published Secchi depths available for Lake Van Basin were reported respectively $189.6 \mathrm{~cm}, 2.1 \mathrm{~m}, 200-980 \mathrm{~cm}, 10-80 \mathrm{~cm}, 0.6-1.3 \mathrm{~m}, 1.77-2.07 \mathrm{~m}, 2.3 \mathrm{~m}, 2.3-2.4$ m, $326.14 \mathrm{~cm}, 10-80 \mathrm{~cm}, 0.5-3.8 \mathrm{~m}, 3.71-6.58 \mathrm{~m}, 1.48-11.04 \mathrm{~m}, 1.9-2.3 \mathrm{~m}, 1.90-5.20 \mathrm{~m}, 6.2$ $\mathrm{m}$ by Çetinkaya et al. (1999), Şener et al. (2010), Buhan et al. (2010), Kıvrak (2015), Erdoğan et al. (2012), Zeybek et al. (2012), Alpaslan et al. (2013), Bilgin (2015), Varol (2015), Kivrak (2015), Alpaslan et al. (2016), Coşkun and Ertan (2016), Kutlu et al. (2017), Çelik and Giritlioğlu (2017), Azgın and Göksu (2017), Tepe et al. (2018). 


\section{CONCLUSION}

As a result of the analysis made on the waters of Lake Aygir, it was found to be firstclass in terms of temperature, $\mathrm{DO}, \mathrm{pH}$, TDS, and second class in terms of OS, according to SKKY. According to 76/464 / EEC, temperature, OS, pH, EC parameters are in the A1 quality class. In terms of TS 266 and UK, temperature, $\mathrm{pH}$, turbidity, and EC parameters were found below the limit values. According to 78/659 / EEC, which states the quality standards of freshwater fish, the temperature and $\mathrm{pH}$ parameters were found to be below the limit values. While the temperature, $\mathrm{DO}, \mathrm{pH}$ parameters related to water quality in trout farming are below the limit values; It has been determined to exceed the limit value in terms of TDS. According to İTASHY, EC, pH; according to WHO, turbidity, TDS; according to EPA, pH and TDS parameters were found to be below the limit values. The turbidity value was slightly above the limit value compared to EPA. Within the scope of in-situ measurements, we can say that the lake water is generally of good quality.

\section{ACKNOWLEDGMENTS}

This study was produced from a doctoral thesis and supported by Van Yüzüncü Y1l University Scientific Research Projects Directorate as the project numbered 2015-FBE-D185. I would like to thank Van Yüzüncü Y1l University Scientific Research Projects Coordination Unit, which provides financial support for this study.

\section{REFERENCES}

Anonymous, 2017. Göller and Sulak Alanlar Eylem Planı 2017-2023. T.C. Orman and Su İşleri Bakanlığı Su Yönetimi Genel Müdürlüğü. Ankara.

Atıc1, A. A., 2017. Karasu Çayı (Van) Kum Alım Faaliyetlerinin Su Kalitesi and İnci Kefali (Alburnus Tarichi, Guldenstaedt 1814) Populasyonu Üzerine Etkileri (doktora tezi). Van Yüzüncü Y1l Üniversitesi, Fen Bilimleri Enstitüsü, Van.

Atıc1, A. A., Gültekin, A., Şen, F., Elp, M., 2016. Erciş (Van) İlçesi içme sularının su kalitesi özellikleri. Yüzüncü Yll Üniversitesi Tarım Bilimleri Dergisi, 26 (4): 517-528.

Aydın, H., 2015. Batlama Deresi Su Kalitesi and Kirlilik Düzeyinin Belirlenmesi (yüksek lisans tezi). Giresun Üniversitesi, Fen Bilimleri Enstitüsü, Giresun.

Bayram, M.S., 2016. Van Gölü’ne Dökülen Güzelkonak (Arpit) Deresi’nin (Gevaş-Van) Su Kalite Kriterleri Üzerine Bir Araştırma (yüksek lisans tezi, basılmamış). Yüzüncü Yıl Üniversitesi, Fen Bilimleri Enstitüsü, Van.

Baytaşoğlu, H., Şen, B., 2015. Keban Baraj Gölü’ne dökülen Haringet Çayı'nın su kalite özelliği üzerine bir araştırma. Fırat Üniversitesi Fen Bilimleri Dergisi, 27 (2): 17-28.

Bulum, Ö. B., 2015. Bendimahi Çayı'nın (Van) Su Kalite Kriterleri Üzerine Bir Araştırma. (yüksek lisans tezi). Yüzüncü Yıl Üniversitesi, Fen Bilimleri Enstitüsü, Van.

Cantürk, N., 2007. Van Gölü’ne Dökülen Akköprü Deresi Su Kalitesinin Incelenmesi (yüksek lisans tezi). Yüzüncü Yıl Üniversitesi, Fen Bilimleri Enstitüsü, Van.

Cirik, S., Cirik, Ş. 2008. Limnology. Ege University, Faculty of Fisheries Press, Izmir, Turkey.

Çavuş A., Şen F., 2018. "Evaluation of Multipurpose Water Uses for Aygır Lake, Bitlis, Turkey", I. International Agricultural Science Congress, VAN, TURKEY, 9-12 May 2018, pp.239-239.

Çavuş, A. 2018. An investigation on water quality and management of Aygır Lake. Van Yuzuncu Yil University. Doctoral thesis. $251 \mathrm{p}$.

Çavuş, A., Atıc1, A., Şen, F., 2017. Van-merkez içme sularının su kalite kriterlerinin incelenmesi. Yüzüncü Yll Üniversitesi Tarm Bilimleri Dergisi, 27(3): 326-336. DOI: 10.29133/yyutbd.265956

Çetinkaya, O., 2003. Su Kalitesi Ders Notları. Yüzüncü Yıl Üniversitesi Ziraat Fakültesi Su Ürünleri Bölümü. Van. 76. 
Assessment In-Situ Measurements In Monitorıng Water Quality Status Of Lake Aygir, Bitlis. Journal of Agriculture, 3(1): $19-27,2020$.

Çetinkaya, O., Sarı, M., Şen, F., Arabacı, M., Duyar, H. A., 1994. Van Gölüne dökülen karasu çayının limnolojik özellikleri. Yüzüncü Yıl Üniversitesi Tarım Bilimleri Dergisi, 4 (1): 151-168.

Dinçer, S., 2014. Çanakçı Deresi Su Kalitesi and Kirlilik Düzeyinin Belirlenmesi (yüksek lisans tezi). Giresun Üniversitesi, Fen Bilimleri Enstitüsü, Giresun.

Dişli, M., 2002. Şanlıurfa Balıklıgölü'nün Su Kalitesi Yönüyle Değerlendirilmesi (yüksek lisans tezi). Gazi Üniversitesi, Fen Bilimleri Enstitüsü, Ankara.

Doğu, A. F., Deniz, O., 2015. Aygır Gölü'nün morfolojik özellikleri and turizm olanakları. Journal of International Social Research, 8 (41): 692-702.

Elp, M., 2002. Koçköprü Baraj Gölü’nde (VAN) Yaşayan Siraz (Capoeta capoeta, G. 1772) and Inci Kefali (Chalcalburnus tarichi, P. 1811) Populasyonlarl Üzerine Bir Araştırma (doktora tezi). İstanbul Üniversitesi, Fen Bilimleri Enstitüsü, İstanbul.

Elp, M., Şen, F., Atıc1, A. A., 2014. İnci kefalinin (Alburnus tarichi (Guldenstaedtii, 1814)) Van Gölü havzası su kaynaklarındaki yayılım bölgeleri. Yuzuncu Yll University Journal of Agricultural Sciences, 24 (3): 228232.

Emre, Y., Kürüm V., 2007. Havuz and Kafeslerde Alabalık Yetiştiriciliği. Posta Basım Evi, Seyrantepe, İstanbul. 272.

Gedik, K., Verep, B., Terzi, E., Fevzioğlu, S., 2010. Fırtına Deresi (Rize)'nin fiziko-kimyasal açıdan su kalitesinin belirlenmesi. Ekoloji, 19 (76): 25-35.

Golterman, H. L., Clymo, R. S., Ohnstad, M. A. M., 1978. Methods for Physical and Chemical Analysis of Fresh Waters. Billing and Sons Ltd. London, 213.

Gülboy, H., 2004. Isparta Deresi and Bazı Yan Kollarında (Ĕ̆rim and Darıören) Su Kirliliğinin Biyolojik and Fizikokimyasal Yönden Belirlenmesi (yüksek lisans tezi). Süleyman Demirel Üniversitesi, Fen Bilimleri Enstitüsü, Isparta.

Güllü, K., Güzel, Ş., 2006. Adilcevaz Hidroelektrik Santralı (Bitlis) Baraj Göletinde gökkuşağı alabalığının (oncorhynchus mykiss, w., 1792) kafeslerde yetiştirilebilirliği and büyüme performansı. Yüzüncü Yll Üniversitesi Tarım Bilimleri Dergisi, 16 (2): 81-85.

Gündoğdu, V., Kocataş, A. 2006. An approach towards the formation of Gediz River basin management plan. Ege Journal of Fisheries and Aquatic Sciences, 23 (3).

Hakanson, L., Jansson, M., 1983. Principles of Lake Sedimentology. Springer, Berlin, 320p.

Henderson-Sellers, B., Markland, H. R., 1987. Decaying lakes. Wiley.

İTASHY, 2005. Insani tüketim amaçlı sular hakkında yönetmelik. (Date: 25.03.2016)

Karagüllü, D., 2015. Coğrafi Bilgi Sistemi (Cbs) Kullanılarak Trabzon İli Söğ̈̈tlü (Kalanima) Deresi Su Kalitesi Parametrelerinin Değerlendirilmesi (yüksek lisans tezi). Karadeniz Teknik Üniversitesi, Fen Bilimleri Enstitüsü, Trabzon.

Kaya, İ., 2015. Amasya Ziyaret Göleti Havzası Su Kalitesi and Sediment Konsantrasyonunun Zamansal Değişiminin Araştırılması (yüksek lisans tezi). Gaziosmanpaşa Üniversitesi, Fen Bilimleri Enstitüsü, Tokat.

Kemmer, F. N., 1988. The Nalco Water Handbook. 2. Bask1, McGraw-Hill Company, New York, NY, United States of America.

Koçer, M. A. T., 2008. Hazar Gölü Açık Bölgesinde Su Kalitesi and Fitoplankton Dă̆ılımı (doktora tezi). Firat Üniversitesi, Fen Bilimleri Enstitüsü, Eskişehir.

Kurmaç, Y., 2003. Aksaray-Uluırmak'ta Su Kalitesi Tespiti and Iyileştirilmesine Yönelik Araştırmalar (yüksek lisans tezi). Niğde Ömer Halisdemir Üniversitesi, Fen Bilimleri Enstitüsü, Niğde.

Nas, S. S., Tüfekçi, M., Bayram, A., Bulut V. N., 2005. Trabzon (Maçka) Kalyan Deresi'nin çözünmüş oksijen profili (sağ eğrisi) üzerine değerlendirmeler. Türk Sucul Yaşam Dergisi, 4: 292-299.

OECD, 1982. Eutrophication of Waters, Monitoring, Assessment and Control. 154 p., Paris.

Ryding, S. O., Rast, W., 1989. Control of eutrophication of lakes and reservoirs. Control of eutrophication of lakes and reservoirs. Parthenon Publishing Group Limited, Carnforth, United Kingdom. 2303. 
Seyhan, Y., 2016. Deliçay (Haydarbey Çayı)'ın su kalite kriterlerinin incelenmesi (yüksek lisans tezi). Van Yüzüncü Yıl Üniversitesi, Fen Bilimleri Enstitüsü, Van.

SKKY, 2004. Su kirliliği kontrolü yönetmeliği, http://mevzuat.basbakanlik.gov.trl Metin.Aspx?MevzuatKod=7.5.7221\&sourceXmlSearch=\&MevzuatIliski=0. (Date: 25.03.2016)

Subka, H. F., 2017. The Comparison of Underground and Desalination Sea Waters Using Due to the Lack of Freshwater Sources in Zuwarah (Libya) (yüksek lisans tezi). Van Yüzüncü Yıl Üniversitesi, Fen Bilimleri Enstitüsü, Van.

Şekerci, İ., 2011. Karasu (Mermit) Çayının (Van) Bazı Su Kalite Kriterlerinin İncelenmesi (yüksek lisans tezi). Van Yüzüncü Y1l Üniversitesi, Fen Bilimleri Enstitüsü, Van.

Şen, F., 1995. Van Gölü Suyuna Gökkuşağı Alabalı̆̆ Adaptasyonu Üzerine Bir Araştırma (yüksek lisans tezi). Van Yüzüncü Yıl Üniversitesi, Fen Bilimleri Enstitüsü, Van.

Şen, F., 2001. Nazik Gölü (Ahlat-Bitlis) Sazan (Cyprinus carpio L.1758) Populasyonu Üzerinde Bir Araştırma (doktora tezi). Atatürk Üniversitesi, Fen Bilimleri Enstitüsü, Erzurum.

Şen, F., 2017. Türkiye'de Su Kaynakları Yönetimi, Söz Sahibi Kurumlar, Gıda, Tarım and Hayvancılık Bakanlığı and Su Ürünleri Uygulamaları, 2023-2071 Vizyonuyla Tarım, (Ed. Sabri Kızılkaya, Hüseyin Öztürk, Fatih Doğan, Şahin Değirmen, Nail Süngü), Semih Sistem Ofset Basım Yayım, Ankara, 208-241.

Şengün, E., 2013. Aksu Deresi Su Kalitesi and Kirlilik Düzeyinin Belirlenmesi (yüksek lisans tezi). Giresun Üniversitesi, Fen Bilimleri Enstitüsü, Giresun.

Tanyolaç, J., 2009. Limnoloji (Tatlısu Bilimi). Hatipoğlu Yayınevi, Ankara. 263.

Taş, B., 2006. Derbent Baraj Gölü (Samsun) su kalitesinin incelenmesi. Ekoloji, 15 (61): 6-15.

Taş, B., Çetin, M., 2011. Gökgöl (Ordu-Türkiye)’ün bazı fiziko-kimyasal özelliklerinin incelenmesi. Ordu Üniversitesi Bilim and Teknoloji Dergisi, 1 (1): 73-82.

Tebbutt, T. H. Y., 1998. Principles of Water Quality Control (Fifth Edition). Elsevier Ltd. ISBN: 978-0-7506$3658-2$.

TSE, 2005. TS 266, Sular-Insani Tüketim Amaçlı Sular. Türk Standartları Enstitüsü, Ankara.

Tuna, A., Ustaoğlu, M. R., 2016. Kemer Baraj Gölü (Aydın-Türkiye) Zooplankton Faunası. Journal of Limnology and Freshwater Fisheries Research, 2 (2): 95-106.

Tuncay, H. 1994. Su Kalitesi. EU Zir. Fak. Yay. No: 512, EU Zir. Fak. Ofset Basımevi, Bornova, İzmir, 243 s.

Turkoglu, M., Oner, C., 2010. Short time variations of winter phytoplankton, nutrient and chlorophyll a of Kepez Harbor in the Dardanelles (Çanakkale Strait, Turkey). Turkish Journal of Fisheries and Aquatic Sciences, 10 (4).

Türkman, A., Tokgöz, S., Sarptaş, H. 1999. İçme suyu standartları and güvenilir içme suyu. 3. Ulusal Çevre Mühendisliği Kongresi. 25-26 Kasım 1999, İzmir.

Yıldız, İ., 2013. Gelevera Deresi Su Kalitesi and Kirlilik Düzeyinin Belirlenmesi (yüksek lisans tezi). Giresun Üniversitesi, Fen Bilimleri Enstitüsü, Giresun.

YSKY, 2012. Yüzeysel Su Kalitesi Yönetimi Yönetmeliği. 30 Kasım 2012 tarih and 28483 sayılı Resmi Gazete. Ankara.

Zeybek, Z., 2006. Akgöl'deki (Karaman-Konya) Bazı Su Kalitesi Parametrelerinin Araştırılması (yüksek lisans tezi). Selçuk Üniversitesi, Fen Bilimleri Enstitüsü, Konya. 